\title{
Article
}

\section{Radically seeking social justice for children and survivors of abuse}

Duckett, Nora and Spandler, Helen

Available at http://clok.uclan.ac.uk/21880/

Duckett, Nora and Spandler, Helen ORCID: 0000-0002-0970-5141 (2018)

Radically seeking social justice for children and survivors of abuse. Critical and Radical Social Work. ISSN 2049-8608

It is advisable to refer to the publisher's version if you intend to cite from the work.

http://dx.doi.org/10.1332/204986018×15199226335123

For more information about UCLan's research in this area go to

http://www.uclan.ac.uk/researchgroups/ and search for < name of research Group>.

For information about Research generally at UCLan please go to

http://www.uclan.ac.uk/research/

All outputs in CLoK are protected by Intellectual Property Rights law, including

Copyright law. Copyright, IPR and Moral Rights for the works on this site are retained by the individual authors and/or other copyright owners. Terms and conditions for use of this material are defined in the policies page.

\section{CLoK}

Central Lancashire online Knowledge www.clok.uclan.ac.uk 


\title{
Critical and Radical Social Work Journal
}

\section{Radically seeking social justice for children and survivors of abuse}

\author{
By Nora Duckett and Helen Spandler
}

\section{Accepted for publication 22 January 2018 - First published online 02 March 2018}

\begin{abstract}
This article explores the contribution of Liz Davies to the radical social work tradition in the UK. We describe two key aspects of Davies' activism: her early mental health activism, supporting foundational organisations like the Mental Patients Union; and her child protection activism, promoting children's rights and obtaining justice for victims and survivors of child abuse. We explore three critical debates specifically arising from her most sustained child protection work: debates about prevention and/or protection; accusation of child abuse activism as moral panic; and the idea of the 'heroic' social work activist.
\end{abstract}

\section{Introduction}

Liz Davies ${ }^{1}$ (b.1948) may not be as well-known as other pioneers explored in this journal, but her work is no less significant. She personifies a radical approach to social work that is concerned with social justice and children's rights to be protected from abuse. For over 40 years she has been a social worker, activist, advocate, campaigner, educator, writer and exposer of social injustice, wherever she sees it and however it is disguised. An indefatigable spirit, she has worked assiduously to bring justice to victims and survivors - of the mental health system and of childhood abuse, most notably, institutional and organised child abuse. We argue this approach is sorely needed today, but is being subsumed into neo-liberal landscapes and attacked by regressive counter-movements.

\footnotetext{
${ }^{1}$ https://lizdavies.net/
} 
This article describes two key aspects of Davies' activism: her early mental health activism; and her most sustained activism focusing on child protection, children's rights and obtaining justice for victims and survivors of child abuse. After outlining her contribution to these areas, we explore some critical debates arising from her work.

\section{Early Mental Health Activism}

In the context of post '68 radicalism, radical social work collectives like Case Con argued that social work professionals should be agents of individual and social change (Weinstein, 2011). Liz Davies was one of many social workers during this time who tried to put this into practice. Graduating in Social Administration from the University of Hull in 1969, her social work career started in the mental health field in the London Borough of Ealing. She was already a keen activist and, as a member of the Young Fabian Society, a socialist campaigning group affiliated to the Labour Party, wrote a pamphlet promoting the idea of permanent homes for people diagnosed with long-term mental illness where they would not be pressured to return to oppressive, exploitative living and working conditions (Durkin ${ }^{2}$ 1971). Today, in an era of mental health 'recovery', this might sound out-dated, but precisely because of this, the demand for adequate long-term supportive housing is still a progressive (and largely unmet) demand.

In 1972 the London Borough of Ealing seconded Davies to undertake formal Social Work training at the London School of Economics where her tutor, George Goetshius, made a lasting impression on her. He, in turn, was inspired by Saul Alinsky, the criminologist, social activist and author of the influential Rules for Radicals (1971). Davies often referred to Alinsky's idea that the activist's job was to 'build confidence and inspire hope' in communities; to fan the 'embers of hopelessness into a flame of fight'; and spot injustice and 'strike it with a hot passion' (Alinsky, 1971 cited in Davies, 2005b: 12). This influence can be seen throughout Davies' long activist trajectory, where she applied it to novel and previously unpopular causes.

${ }^{2}$ At this time, Davies was writing under the name Elizabeth Durkin, from her first marriage. 
As a student social worker her practice placement was with the radical therapeutic community at Paddington Day Hospital (PDH). This unit focused on group psychotherapy and refused to impose forms of medication or treatment including Electro Convulsive Therapy (ECT) in the belief that these placed the locked doors inside the patient. In therapy groups power structures were continually questioned and patients were encouraged to develop their own individual and collective agency (Durkin, 1972: 14). In 1971, when PDH was threatened with transfer to a more medical unit, Davies co-ordinated the campaign to save it, with the full support of her tutor, Goetshius. That became the focus of her placement activity, probably a far cry from many students' experience of social work placements today.

The campaign quickly snowballed, drawing in large numbers of people who were becoming politicised around mental health. Davies discussed the campaign with Goetshius, who suggested fabricating a date that the decision about transferring the day hospital would be made. To keep the momentum of the protest alive, the campaign group adopted this tactic and circulated the fictitious date. On this date, Davies called the Ministry of Health and was informed that the proposed closure was abandoned and that staffing levels would be strengthened. Following the campaign's success, Davies wrote a paper called 'Patient Power: A Review of a Protest' (Durkin 1972) which predated the idea of 'user involvement' and surpassed its rather narrow remit that has become accepted within policy and practice. In particular, she explicitly linked the idea of 'patient power' with the therapeutic community being developed at Paddington. Reading this paper directly inspired one of the authors of this piece to research the history of $\mathrm{PDH}$, and its role in the rise of the mental patients' movement (Spandler, 2006).

Directly after the campaign, a small group - Davies, Brian Douieb (her partner), Eric Irwin (a patient) and Lesley Mitchell (an occupational therapist), and later, Andrew and Valerie Roberts (both patients) - continued to meet and discuss what to do next. They produced a document 'The Need for a Mental Patients Union' (see Durkin and Douieb, 1975) which was circulated in 1972 and became well-known within the emerging patients' movement as the 'fish pamphlet' (because of its cover image of a hooked fish). The idea of a union drew on the need for collective representation and the pamphlet was directly inspired by the labour movement and influenced by Marxism. 
Yet it extended, or challenged, the conventional notion of social class to incorporate patients. They even wrote to the Trade Union Congress to request patient membership, but received no reply. Later, Davies and Douieb wrote "client control is as threatening to the power structure as workers' control" (Durkin and Douieb, 1975:191). Presciently, they warned that patients were being enticed into service provision as a devious method of absorbing dissent and dividing them from other oppressed groups (ibid: 191). The fish pamphlet inspired the mental patients' union and subsequent Mad Pride activists, who re-produced it in their Mad Pride anthology (Curtis, et al., 2000). When the national Mental Patients' Union was formed in 1973, it reserved full membership for patients and ex-patients. Duly inspired, but not an identified patient, Davies went on to apply her newly acquired activist skills elsewhere.

Although Goetshius' Community Action course that so influenced Davies, was discontinued in 1973, she continued to put into practice the approach to social work as community action she had learned. However, her burgeoning social work career faced a number of setbacks. Davies left Ealing as a result of the Director of Social Services telling her that because her first marriage had ended, she was unsuitable for social work. This was echoed a few years later when, after the tragic deaths of two of her children, she was told a grieving parent wouldn't make a good social worker. Despite, or perhaps because of this, she went on to make a lasting mark on the profession.

Davies first worked as a social worker in Islington and then taught a Mental Health and Social Action course at Middlesex Polytechnic. During this time, she applied William Ryan's notion of 'victim blaming' (Ryan, 1970) to critique social workers' complicity in social injustice and inequality. She warned that social workers were displacing responsibility for scarce resources onto clients, and blaming them for their situation, especially when feeling powerless and guilty about their inability to change a client's situation:

"[Social workers] are as helpless as their clients in the face of the economic and social evils of this society. So they frequently blame clients for the position they are in... The social workers protected themselves from the full horror of the situation. As a result they protected not only themselves, but the establishment they are part of" (Durkin, 1973: 2059). 
Again, this article was prescient. It anticipated problems increasingly facing social workers in more recent conditions of austerity. For example, some critics argue that mental health recovery policy can be used by workers as a 'stick to beat service users with' especially clients are not able to 'recover' in accepted ways i.e. to return to employment; and not need services or disability benefits (Spandler, 2014; Recovery in the Bin, 2016). However, it also prefigured Davies' subsequent laying bare of senior managers' complicity in protecting themselves and the establishment from accusations of covering up abusive practices within services.

Between 1975 and 1977, while working as a Child and Adolescent Mental Health social worker in Bedfordshire, Davies and Douieb were part of a collective setting up radical community bookshops; Partisan Books in Luton and Visions in North London, both part of the Federation of Alternative Bookshops, providing access to literature from, black power, men against sexism, lesbian/gay and women's liberation movements. They lived and worked in the shops and associated communes and organised and supported community activism including, crèches, squatting, community wholefoods, vegetarianism, legal and welfare rights and community newspapers. For example, they were involved in a campaign to secure agreement from a housing association that homeless people could squat houses until they were ready to renovate. The campaign identified empty houses and provided information about housing legislation and loopholes to protect the squatters from arrest and eviction. In turn [residents] "cared for each other's children, made food together and created communal gardens and food co-ops" (Davies, 2005b: 12).

It was an exciting time of non-stop activism and intense debates about political theory and analysis on the dynamics of activism as it was taking place. There were also negative experiences that conceivably damaged Davies' ideal of collectivism and deepened her commitment to think critically and reflexively. For example, she experienced difficulties with communal childrearing and anti-men sentiments. More significantly, she also became aware of radical bookshops being supplied with Paedophile Information Exchange (PIE) literature under the guise of children's liberation and 'rights' to have sex with adults. She was quick to recognise this as a form of child abuse. As we shall see, her vigilance about otherwise progressive 
organisations condoning, justifying or even promoting the sexual abuse of children would soon resurface.

\section{Child Protection Activism}

In the late 1980s Davies worked at the Irene Watson Neighbourhood Office in the London Borough of Islington. Unlike now, social work neighbourhood offices were accessible to the local community which enabled children, their carers, local residents and community groups to directly access teams and express any concerns. This is how Davies first heard about the abuse happening in Islington's children's homes and led to her being a key whistleblower in exposing what was to become a notorious national child abuse scandal (Fairweather, 1998).

Davies was responsible for placing children in foster care and children's homes across the borough. However, she gradually discovered that instead of being safe and nurtured, some children were being sexually and physically abused by staff and others. Davies and her co-workers noticed an increase in the number of children visiting their offices and waiting outside in the morning as they arrived to begin the working day. 'It was like a queue,' she remembered in an interview she gave to the Guardian Newspaper in 2003. She recalled a day when two boys came to the office, one looked afraid while the other reassured him: 'it's all right' he said, 'she's not one of them' (Harris and Bright, 2003). This brief comment provided Davies with a clue to what was taking place.

Over time she noticed patterns of worrying behaviour in the children (depression, feeling suicidal, self-harming, sleeping rough and getting into trouble with the police), all suggestive of abuse. In addition, local parents told staff that young people were being 'picked up in vans and taken out of the area at night' (Davies 2003). The children, who often had histories of neglect and abuse in their families, told Davies and her colleagues about children being groomed by adults and sometimes by older children to be sexually abused in care homes and private houses. Davies started to suspect that an organised network of child abusers was operating in the area. 
In 1990 Davies and her manager, David Cofie, raised their concerns at a forum of local residents, talking directly to Margaret Hodge, (then the local ward councillor). However, their requests for additional resources to investigate and protect the children were denied. Police and social services' managers said there was no evidence of abuse, that they were exaggerating and instructed them to cease their investigations. Despite this, along with colleagues in health, education, probation and police, Davies continued to listen and record children's accounts. She submitted 15 reports to senior managers and the Area Child Protection Committee (ACPC) (now Local Safeguarding Children Boards). The ACPC considered the allegations and declared that there was no foundation to them (White and Hart, 1995). Yet Davies was not satisfied and continued to raise concerns. Finally, when instructed to place a seven-year-old child with foster carers about whom she had raised concerns of suspected child abuse, she made the decision to leave the authority; she felt this was the last straw and her position was untenable (Harris and Bright, 2003).

In 1992, while working as a child protection manager in the London Borough of Harrow, Davies told Scotland Yard police what was happening in Islington. This led to an exposé in the London Evening Standard Newspaper followed by local and national press coverage ${ }^{3}$. The reports described a care system infiltrated by active child sex offenders and of senior local authority employees failing to take action to protect children when they had the opportunity. The council, then led by Margaret Hodge, initially denied the stories and 13 subsequent inquiries dismissed claims of a sex offender network (Dean, 2015). Yet in 1993, The Sunday Times newspaper stated that police reported a 'child sex ring' in Islington where "some of the most prominent offenders under surveillance are prominent businessmen" (Palmer, 1993). Davies' and her colleagues' claims were vindicated in the media, and through survivor testimony (BBC, 2014; Youle, 2017b). However, the true extent of organised abuse crimes against children remains unknown; perpetrators have not been held to account; and survivors have not achieved justice (Davies, 1997). Because of this, Davies continues to campaign for a police-led investigation into alleged abusers and for action to be taken against those who colluded with the abuse (Youle, 2017a).

\footnotetext{
${ }^{3}$ See https://spotlightonabuse.wordpress.com/category/islington/
} 
For more than a decade Davies' identity, as the key whistleblower in the Islington child abuse scandal, was protected by the police and media. It was not until 2003; when she took up a post as a social work lecturer at London Metropolitan University, that she waivered her anonymity. She 'came out' at the request of survivors who were protesting about Margaret Hodge becoming Minister for Children (Davies, 2003a; Davies, 2014c).

Her move into academia from practice was based on the advice of the head of London's Metropolitan Police's Obscene Publications Branch, who was concerned about her and her family's safety. The move provided a platform to write, lecture, campaign, influence child protection practice and complete her doctorate (Davies, 2010a). She also defended and supported social workers who were not complicit but who were scapegoated in notorious and tragic child deaths. For example, she acted as an expert witness for Lisa Arthurworrey, Victoria Climbié's allocated social worker; and for two social workers in the case of the death of Peter Connelly (known in the media as 'Baby P').

She wrote several articles exploring responses to these child deaths, including the decision to place Arthurworrey on the Protection of Children Act list (Davies, 2005a; 2009a; 2010b; Jarman and Davies, 2005). For more than ten years she fought for Arthuworrey's removal from this list and her reinstatement on the professional social work register. Davies recognised that Arthurworrey had been scapegoated and had not been properly trained or supported. She argued that this, combined with an overt 'family support' policy, instead of pro-active child protection, played a significant part in the tragedy:

"The question that should always have been asked about Ms Arthurworrey's involvement in the Victoria Climbié case was not why she failed, but how she was ever expected to get it right in the context of the chaos of Haringey council services at the time and the government steer away from interventionist strategies?" (Davies, 2005a).

As child protection is so central to her activism, the following sub-sections identify three key contributions Davies has made to this field. 
Highlighting the impact of policy reforms on child protection

A key thread throughout Davies' activism has been resisting policy developments which undermine child protection practice. For example, she criticised the curtailing of child protection powers and procedures under successive governments, such as the abolition of the child protection register (Davies, 2008a; Davies, 2009b; Education Select Committee, 2011) and the closure of joint police and social work child protection teams (Davies, 2008b; Davies, 2014b). In addition, she spoke out against revised statutory guidance which eliminated the definition of organised abuse and the means of investigating it, thereby making it even harder for social workers to protect children from organised and institutional abuse (Davies, 2014b; Davies, 2016c). More generally, she has been highly critical of policies that have led to the erosion of child protection systems and practices that have otherwise worked well (Davies, 2008c; Davies, 2009b; Davies, 2016c).

In addition, she was critical of the lack of scope and terms of reference of the Independent Inquiry into Child Sexual Abuse (Davies, 2016b) and scathing of developments in social work education, such as the national roll-out of 'fast track' social work training programmes (Davies, 2016a). She explicitly located the lack of protection for children within the wider neo-liberal context of increased marketisation, reduced state intervention and deregulation (ibid). During the New Labour government she criticised the move to 'care management' which she argued "made social workers' primary role that of the conservation of local authority resources (under strict management procedures) rather than the empowerment of service users" (Davies 2005b: 13). Austerity and new managerialism has meant a primary focus on efficiency, which can mean cutting corners, being dictated to by budgets and resourcing, and professionals being rebranded, repositioned and disempowered. All this, she argued, makes the occurrence of mistakes more likely and ultimately children less protected. In conversation, Davies recently made a connection between this situation and the recent horrific fire at Grenfell towers in London, which took so many lives ${ }^{4}$. Both arguably illustrate the dangers of state deregulation, privatisation

\section{${ }^{4} \mathrm{https}: / /$ grenfellactiongroup.wordpress.com/2017/06/14/grenfell-tower-fire/}


and the need for protective state intervention and the pro-active involvement of professionals

\section{Speaking truth to power}

Davies took the idea of 'speaking truth to power' seriously, and at some personal risk. Her role in uncovering abuse and seeking justice for children is described (anonymously) in a chapter by the journalist Eileen Fairweather in Geoffrey Hunt's (1998) Whistleblowing in the Social Services. She writes that had it not been for:

"... the determination of one key whistleblower, who tirelessly gathered evidence and persuaded others to talk...[and] had the Standard [Newspaper] not constantly pushed the agenda, in the face of council lies and an initially half-hearted response by the Department of Health and police, Islington's children's homes would still be controlled by paedophiles, pornographers and pimps" (Fairweather, 1998: 20).

Parallels can be drawn between Davies and other whistleblowers. For example, workers in Rochdale and Rotherham who repeatedly drew attention to child abuse, where other professionals were unwilling or unable to see that children needed proactive protection. Known examples include Margaret Humphreys (2011) who fought for child migrant's rights; Sue Richardson in the Cleveland child abuse case (Tate, 1998); Adel Galdman and Jayne Senior in Rotherham and Sara Rowbotham, the NHS worker who tried to expose the abuse of children in Rochdale (dramatized in the BBC production Three Girls). These were all women fighting tirelessly for their suspicions and evidence of child abuse to be taken seriously and thoroughly investigated. All were able to attend to what others refused to see or didn't believe.

In 2014 Davies called for a national inquiry to help piece together connections between abuse taking place in Islington, and across the country. She cited the need to re-examine child murders and the unexplained deaths of children who had lived in 
Islington's children's homes, and to search for missing dossiers of evidence. Finally, in a House of Commons Public Meeting: 'Child Abuse Inquiry: Time for Action and Justice' in January 2015, Davies made an impassioned speech summarising her long struggle for justice:

"For 25 years some of us have been whispering in dark corners and today we are shouting out loud. It is a very significant turning point in our campaign which has two main aims; to protect current children and to gain justice and healing for survivors. This means also seeking the prosecution and conviction of perpetrators and removing them from the world of children...The Dirt Books, the Government Whip's records of MPs 'misdemeanours', including sexual harm to children, kept in the safes of this very building, were used to control the actions of MPs and have still not been seized by police. This is a disgrace ... Those in power can destroy all the records they want but we have our memories. None of us will ever forget what we have seen and witnessed ...We will not stop until we get the Chair of the Inquiry we want, the Panel we want, the Terms of Reference we want and the Safeguarding protocols we want. Today we have come out of the shadows and there's no going back" (Davies, 2015, cited on http://islingtonsurvivors.co.uk/whiteflowers/).

Since officially retiring in 2015, Davies has continued to campaign for a full investigation into organised child abuse; for justice for survivors of abuse; and for child sex offenders to be held to account. Her attempts to expose those who have used their positions to abuse, cover up, or turn a blind eye to child abuse, including politicians, but also senior officers in social services whose jobs involve protecting children, are on-going. For example, new evidence has been uncovered that a former Islington Councillor who had a significant role in the 1990's inquiries had previous links with pro-paedophile organisations (Youle and Alwakeel, 2017). Alongside survivors, Davies set up the Islington Survivors' Network (Islingtonsurvivors.co.uk), which collates testimony about abuse in Islington's children's homes and campaigns for the rights of victims and whistleblowers (Youle, 2017a).

Exposing abuse, wherever it occurs 
Davies' other key contribution was her willingness to speak out, even when it wasn't considered a suitably 'radical' or credible cause. As such, she wasn't celebrated or popular within social services or even amongst other radicals. She argued that social workers must be prepared to recognise child abuse in all social classes and contexts. She challenged prevailing attitudes on both the political right and left that the children of the rich and privileged did not require social work involvement. For example, she worked closely with a police colleague to develop safe and creative ways to enable children to disclose abuse in boarding school environments (Davies and Townsend 2008b). For Davies, structural and class-based approaches to tackling child abuse were inadequate. For her, whilst the predominant (Marxist) radical social work tradition helped to highlight class inequalities, it did not sufficiently address the oppression and exploitation of children by adults, which she termed 'childism' (Davies and Townsend, 2008a; Davies and Kerrigan Lebloch, 2013a; Davies and Duckett, 2016).

Whilst aware of the negative consequences of capitalism or neo-liberalism on children's lives, she was critical of any tendency to reduce social problems like child abuse to social structures as it can absolve responsibility for taking action:

"I understand the nature of an oppressive state which is punitive to the poor and all that a class-based perspective analysis of the social work role provides... However, currently thousands of survivors of abuse are giving testimony of how they were failed by the services which had the power to protect them" (Davies, 2015: 13).

Arguably, her lack of allegiance to any overarching theory or ideology allowed her to challenge any implicitly held assumptions which might have resulted in condoning abuse. For example, she was aware of the potential for child abuse across genders, ethnicities and sexualities, as well as social class. If she believed someone was involved in promoting, or covering up, abuse, they were not immune from scrutiny, whatever their social status or political persuasion, including politicians, senior social workers or even other activists. For example, she was quick to call out libertarians in the 1970's sexual liberation movement who were sometimes complicit in, or 
supportive of, adult-child sexual relations, sometimes even considering 'paedophilia' as an oppressed sexuality.

In addition, unlike many radicals, she welcomed the power of the state and the mainstream media in investigating child abuse and attempting to bring perpetrators to justice. For example, she consistently argued for the reinstatement of joint working with police; the need for a national police led multi-agency child protection investigation team (Davies, 2016b); and building relationships with the local and national media (Davies 2014a). In this way, Davies' work has much in common with feminist activism which calls for extending powers of the state to actively intervene and protect women and prosecute perpetrators of violence against women. This approach has tended to be less popular with other radicals on the left who are more suspicious of the police and the media.

\section{Theoretical and Critical Debates}

Davies has referred to the type of interventionist and investigative practice she promoted as 'authentic' social work (Davies, 2005b:12). However, her work raises a number of questions for social work practice today. We have chosen to focus on three key challenges here.

\section{Child Abuse: prevention and protection}

In the 1990s prevention as a concept grew in significance. Child protection systems were seen as alienating (mostly poor) families and placing too much emphasis on child abuse investigations to the detriment of prevention and addressing underlying social problems (Parton, 1997). Subsequent policy measures under the New Labour government refocused attention away from child protection to prevention/early intervention services (such as Sure Start and Connexions) as a way to tackle the underlying causes of crime and social exclusion (Parton, 2006). However, in the aftermath of the death of Peter Connelly, from 2007, a significant increase in the number of child protection investigations and conferences (McNicoll, 2016) and court proceedings applications (Mumby, 2016) suggests the pendulum had swung back towards child protection interventions. 
The question of whether policy should focus on proactive and investigative child protection or prevention and addressing underlying needs continues to animate debates in social work. The dominance of child protection, it is argued, has led to a distortion in practice where social workers insufficiently attend to the impact of poverty and inequality and penalise poor families and that the priority should be on addressing underlying 'needs' instead (Featherstone, 2015; Mellon, 2015). Davies, however, maintains that prevention focused policies that eclipse child protection practices leave children more at risk and that this also occurred through devaluing professional investigative skills and instating universalist approaches such as standardised assessment methods (Davies, 2015).

For Davies, prevention versus protection is a false dichotomy as they are two essential, yet distinct, strategies in the protection of children from harm. In addition, she argued that whilst poverty and inequality contribute to misery and may increase children's lack of safety and vulnerability, they are not synonymous with abuse. Therefore, separate child protection powers are necessary. Furthermore 'prevention' she argued should include removing child sex abusers from a child's world; learning from survivors of abuse; and mobilising local communities to become more aware of how to identify and report abuse, such as neighbourhood mapping schemes and the creation of networks of protective adults (Nelson and Baldwin, 2004; Davies, 2004; Nelson and Davies, 2016).

Whilst prevention or protection may be a false distinction, for social workers practising in an often fraught and complex field, with reduced funding and resources, overwhelming caseloads and over-proceduralised approaches, they may be faced with a stark choice about priorities. For Davies, protecting children requires significant resources and an immediate and uncompromising approach (Douieb, 1991), whilst prevention is perhaps a longer-term project, which, while no less important, must not be conflated with protecting children in the here and now.

Child abuse activism and moral panic 
The kind of proactive investigative social work that Davies advocates has not only been seen as misguided and risk-averse, but also as contributing to a 'moral panic' around child sexual abuse (Clapton et al., 2012; Cree, et al., 2016). Proponents of this argument claim that child protection activism tends to overstate and overestimate the scale of the problem, creating anxiety, fear and victimhood. They are especially critical of activists' use of the media which sensationalises abuse and 'paedophilia' which they argue contributes to a cultural climate of suspicion, distrust and powerlessness. Whilst not denying child abuse per se, they claim that concerns about child abuse are exaggerated, irrational and ultimately damage benign relationships between adults and children. According to these critics, child abuse is a 'policy storm in a tea cup, which is unfair to those accused, a waste of investigatory resources and another incursion of state power to limit our citizenship' (Pilgrim, 2017 16-17).

If true, this assessment is pretty damning of Davies' activism. Clearly, there is an undeniable problem with media sensationalism feeding off stories of abuse and promoting cultures of blame and shaming public figures, However, it is worth noting that the media equally sensationalise 'false allegation' stories just as much as they relish abuse exposés. In addition, and more importantly, empirical examination suggests there is 'no case at all for child sexual abuse being a moral panic' (Pilgrim, 2017: 16).

The notion of moral panic was re-worked and popularised by Stanley Cohen (1972) in his classic Folk Devils and Moral Panics. The 'folk devil' is society's cultural deviant; provoking widespread anger and disgust and is disproportionately and erroneously seen as the cause of social ills (Cohen famously applied this to 1960's mods and rockers). Contemporary moral panic proponents see the 'paedophile' as the modern day 'folk devil' (Cree, et al., 2016). Furedi (2016) even compares paedophiles to witches. Therefore, by implication, child protection advocates like Davies, are equivalent to 'witch-finders' (Pilgrim, 2017). Whilst child abuse might provoke widespread anger and disgust, Pilgrim argues that this is not unwarranted or disproportionate to the scale of abuse, or the harm caused. Rather, he suggests the focus should be on how 'moral panic claim-making is diverting our serious attention from the scale and impact of child sexual abuse' (ibid: 18). 
Similarly, with the Labour MP Tom Watson, Davies wrote:

"The concept of a 'moral panic' is an academic argument being exploited to attack those who are striving to protect children from harm. They would never say that those who oppose racism are part of a moral panic so why apply it to those who oppose childism?...Further, it...ignores the evidence of the experiences of abused children, the experiences of adult survivors of child abuse and the experiences of many professionals who work to protect children" (Watson and Davies, 2013b5).

However, critics argue that pursuing historic allegations of abuse perpetuates a victim and compensatory culture, suggesting continued efforts to secure justice for survivors is potentially harmful (see, for example, Hewson, 2015). It is worth noting, however, the continued harm that child abuse can cause victims and their families, especially when it has not been fully acknowledged. Survivors' accounts suggest that the effects of abuse can continue through generations, a phenomenon often conceptualised as 'trans-generational trauma' (Fromm, 2012). Indeed, if anything, rather than a 'witch finder', perhaps Davies' persistent and courageous efforts to bring perpetrators to justice might be more comparable to Nazi hunters, like Simon Wiesental. Indeed her activism resonates with the views of holocaust survivor Stéphane Hessel (2011: 17):

The worst possible outlook is indifference that says 'I can't do anything about it or l'll get by'. Behaving like that deprives you of one of the essentials of being human: the capacity and the freedom to feel outraged. That freedom is indispensable, as is the political involvement that goes with it.

Having said that, it may be that a focus on 'childism' produces its own blind spots. Risk averse child protection policies may inadvertently construct children as, by definition, vulnerable and unable to make their own decisions and their care overscrutinised as a result. On balance, however, protecting children from abuse must surely always be a priority. Too many mistakes have been made, with long-term consequences to individuals, communities and societies. Activists like Davies have

\footnotetext{
${ }^{5}$ https://lizdavies.net/academia/publications/comment-2/
} 
put this issue firmly on the agenda and ultimately this is surely a positive development and one which furthers a much-needed understanding of organised abuse (Salter, 2013).

\section{The heroic activist}

Finally, it could be argued that our portrayal of Davies resonates with what has been described as a 'heroic' social work activist, characterised by a 'willingness to 'recognize systemic injustices and their preparedness to take a stand' (Healy, $2000: 135)$. This ideal of the 'heroic agent' who is portrayed as being able to achieve social justice and social change when armed with 'truth' and relevant 'facts', has been criticised as idealistic and naïve (Marston and McDonald (2012). Critics argue that social workers need to be more realistic and humble about what they can achieve, and concentrate on more modest goals, lest it lead to demoralisation. Clearly, especially in the current context of social work practice, the extent to which workers can achieve wider social change may be questionable.

Actually, Davies' story aptly illustrates both the possibilities and limitations of the radical social worker. Perhaps it's not surprising that Davies' more public activism often peaked when she wasn't working as a practitioner or manager: for example, when she was a student in the context of post-68 radicalism; when she left social work to enter academia; and then upon retirement. At the same time, she was clearly able to make a difference, to individuals and communities while in practice, even if this was a continual struggle, and at times an unfinished project. Indeed, it was precisely the small-scale acts, like pro-actively listening to children, which enabled her to see the 'bigger picture'. As Alinsky (1971:75) reflects, it is an awareness of this that can strengthen the activists' role in what can sometimes seem like overwhelming odds:

It is as though as an artist he [sic] is painting a tiny leaf. It is inevitable that sooner or later he will react with 'What am I doing spending my whole life just painting one little leaf? The hell with it, I quit'. What keeps him going is a blurred vision of a great mural where other artists - organizers - are painting their bits, and each piece is essential to the total. 
Therefore, we think Davies should be added to the list of radical pioneers who will hopefully continue to inspire future generations of social workers and activists. Like any pioneer, she didn't act alone, but required the active support of colleagues and trusted allies, including, most significantly, survivors themselves.

\section{Conclusion}

Given increasing awareness of the pervasiveness and long-term effects of abuse on mental health, Davies' pioneering activism in these areas is increasingly relevant and necessary. Her contribution has been primarily practical rather than theoretical, organised around the central principle that survivor's and children have the right to be heard, valued and protected. Her approach eschews theory that intellectualises abuse over grassroots activism. Yet, it can be supported theoretically and empirically (see, for example, Pilgrim, 2017). This activism has enabled the plight of survivors of abuse and of the mental health system - to be included within a continually evolving radical social work tradition. In particular, it helped facilitate a deeper engagement with, and understanding of, the powerful forces that continue to silence, cover up and collude with, child abuse.

\section{References}

Alinsky, S. (1971) Rules for Radicals: A Pragmatic Primer for Realistic Radicals Random House, New York

BBC (2014) 'Calls for inquiry into Islington abuse allegations' BBC News http://www.bbc.co.uk/news/av/uk-england-london-29496151/calls-for-inquiry-intoislington-abuse-allegations (Accessed 14th January 2017)

Cohen, S. (1972) Folk Devils and Moral Panics. The Creation of the Mods and Rockers. London: MacGibbon and Kee Ltd

Curtis, T., Dellar, R., Esther, L. and Watson, B. (2000) Mad Pride: A Celebration of Mad Culture. London: Spare Change Books

Clapton, G., Cree, V.E. and Smith, M. 2012. Moral panics and social work: towards a sceptical view of UK child protection. Critical Social Policy. 33(2), 197-217 
Cree, VE, Clapton, G, Smith, M (eds), 2016, Moral panics in theory and practice, Bristol: The Policy Press

Davies, L. (1997) 'The Investigation of Organised Abuse' in Westcott, H and Jones, J. Perspectives on the Memorandum. London: Arena

Davies, L. (2003) Children's Minister post is too important to get wrong. Society Guardian online. $1^{\text {st }}$ July 2003

https://www.theguardian.com/society/2003/jul/01/childrensservices.politics (Accessed $27^{\text {th }}$ June 2017)

Davies, L. (2004) 'The difference between child abuse and child protection could be you'. Child Abuse Review. Vol. 13: 426-432

Davies, L. (2005a) The Right Decision. Society Guardian online 9th June www.guardian.co.uk/society/2005/jun/09/comment.childprotection (Accessed 11 $1^{\text {th }}$ January 2017)

Davies, L. (2005b) Authentic Practice Works. Professional Social Work. Birmingham: BASW. December 2005: 12-13

Davies L (2008a) 'In the shadow of a tragedy'. Society Guardian online. 28th January http://www.guardian.co.uk/society/2008/jan/28/Climbié.childprotection (Accessed 20th June 2017)

Davies, L. (2008b) 'Reforms have been imposed at the expense of protecting children' Society Guardian online. $2^{\text {nd }}$ December 2008

https://www.theguardian.com/society/joepublic/2008/dec/02/baby-p-child-protectionsocial-work (Accessed 20th June 2017)

Davies, L. (2008c) 'Reclaiming the language of child protection'. In M. Calder. (Ed) (2008) Contemporary risk assessment in safeguarding children. Dorset. Russell House

Davies, L. (2009a) 'Let's get rid of social work's blame culture' The Guardian On Line. 25th June. www.theguardian.com/society/joepublic/2009/jun/25/social-work-baby-pvictoria-climbie (Accessed 20th May 2017)

Davies, L. (2009b) 'Response to Laming'. Professional Social Work. Birmingham: BASW. April 2009

Davies, L. (2009c) Safeguarding Children in R. Adams (Ed) (2011) Working with Children and Families. Knowledge and Contexts for Practice. Hampshire. Palgrave Macmillan

Davies, L. (2010a) Protecting Children - A Critical Contribution to Policy and Practice Development. https://izdavies.net/academia/publications/\%20phd-thesis/ (Accessed $2^{\text {nd }}$ July 2017) 
Davies, L. (2010b) 'A ten year struggle: The story of Victoria Climbié's social worker'. Professional Social Work. Birmingham: BASW. May 2010

Davies, L. (2014a) 'Working positively with the media to protect children Journal of Social Welfare and Family Law, 36:1, 47-58

Davies, L. (2014b) 'Unanswered Questions: Comment by Liz Davies on why she wants a national inquiry'

https://spotlightonabuse.wordpress.com/2014/07/17/unanswered-questionscomment-by-liz-davies-on-why-she-wants-a-national-inquiry/ (Accessed $7^{\text {th }}$ August 2016)

Davies, L. (2014c) 'Open letter to Margaret Hodge MP' $3^{\text {rd }}$ August 2014.

https://lizdavies.net/academia/publications/comment-2/ (Accessed $6^{\text {th }}$ June 2017) Davies, L. (2015) 'Focus must be on needs and Risks or we will fail to protect children' Professional Social Work. July 2015

Davies, L. (2016a) 'Doublespeak and Frontline' 9th July https://lizdavies.net/2016/07/09/doublespeak-and-frontline/ (Accessed 20 ${ }^{\text {th }}$ December 2016)

Davies, L. (2016b) 'Goodbye' Goddard though I never said 'Hello' $11^{\text {th }}$ August. https://lizdavies.net/2016/08/11/goodbye-goddard-though-i-never-said-hello/ (Accessed 20 ${ }^{\text {th }}$ December 2016)

Davies, L. (2016c) 'Protecting children from organised sexual crime'. $12^{\text {th }}$ April. https://lizdavies.net/2016/04/12/protecting-children-from-organised-sexual-crime/ (Accessed 20 th December 2016)

Davies, L. and Duckett, N. (2016) Proactive Child Protection and Social Work. London: Sage/ Learning Matters

Davies, L. and Kerrigan Lebloch, E. (2013a) Communicating with Children and Their Families: Responding to Need and Protection. Milton Keynes. Open University Press

Davies, L. and Townsend, D. (2008a). The Investigative Interviewing Of Children: Achieving Best Evidence. Working Together - Training Together. London: Russell House Publishers

Davies, L. and Townsend, D. (2008b). Joint Investigation In Child Protection. Working Together - Training Together. London: Russell House Publishers

Dean, J. (2015) 'Child abuse expert vows to fight on until 'whole sordid picture' of Islington's paedophile ring revealed' Islington Gazette.

http://www.islingtongazette.co.uk/news/crime-court/child-abuse-expert-vows-to-fighton-until-whole-sordid-picture-of-islington-s-paedophile-ring-revealed-1-3917191 (Accessed 20 ${ }^{\text {th }}$ December 2016)

Douieb, L. (1991) 'I have done a dawn raid. I have no apologies'. The Independent Newspaper. 24th March 
Durkin, E. (1971) Hostels for the Mentally Disordered. Fabian Society, London

Durkin, L. (1972) 'Patient Power; Review of a protest Social Work Today 3(15):13-15

Durkin, L. (1973) Victim blaming. Health and Social Service Journal. 8th September 1973

Durkin, L. and Douieb, B. (1975) 'The mental patients' union.' In D. Jones and M. Mayo Community Work Two. London: Routledge and Kegan Paul

Education Select Committee (2011) - Children first: the child protection system in England.

http://www.publications.parliament.uk/pa/cm201213/cmselect/cmeduc/137/137vw17. htm (Accessed $8^{\text {th }}$ June 2017)

Featherstone, B. (2015) 'Needs not Risk should be Priority'. Professional Social Work. June 2015

Fairtweather, E. (1998) 'Exposing Islington's children's homes scandal: A journalist's view' in G. Hunt (1998) (Ed) Whistleblowing in the Social Services. London: Arnold

Fromm, M.G. (2012). Lost in Transmission: Studies of Trauma Across Generations, London, Karnac Books

Furedi, F, (2016) 'The moral crusade against paedophilia', in VE Cree, G Clapton and M Smith (eds) Moral panics in theory and practice, Bristol: The Policy Press

Harris, P. and Bright, M. (2003) The whistleblower's story. The Guardian. 6th July. http://gu.com/p/kgfy/sbl (Accessed 1st June 2017)

Healy, K. (2000) Social Work Practices: Contemporary Perspectives on Change. London: Sage

Hessel, S (2011) A Time For Outrage. London: Quartet Books

Hewson, B, (2015) Compo culture and the child abuse panic: historic sex abuse claims have fuelled the UK's compensation industry, Spiked, 6 July

Humphreys, M. (2011) Empty Cradles: One Woman's Fight to Uncover Britain's Most Shameful Secret (Oranges and Sunshine). London: Random House

Jarman, M. and Davies, L. (2005) Social worker's professional practice after Climbié. Family Law.35: 814-819

Marston, G. and McDonald, C (2012). 'Getting Beyond 'Heroic Agency' in Conceptualising Social Workers as policy actors in the Twenty First Century.' British Journal of Social Work 42: 1022-1038

McNicoll, A. (2016) 'Rise in child protection cases ups pressure on services' Community Care. $4^{\text {th }}$ November 2016 
Mellon, M. (2015) Dominance of child protection rather than welfare has reduced faith in social workers. Professional Social Work. November 2015

Mumby, J. (2017) View from the President's Chambers - Care cases: The Looming Crisis. https://www.judiciary.gov.uk/wp-content/uploads/2014/08/pfd-view-15-carecases-looming-crisis.pdf (Accessed 20th June 2017)

Nelson, S. and Baldwin, N. (2004). The Craigmillar project: neighbourhood mapping to improve children's safety from sexual crime'. Child Abuse Review, Vol. 13: 6: 415425

Nelson, S and Davies, L. (2016) 'Models for more effective child protection. In S. Nelson (2016) Tackling child sexual abuse: Radical approaches to prevention, protection and support. Bristol. Policy Press

Palmer, R. (1993) “Child Abuse Sex Ring Found”. The Sunday Times. $1^{\text {st }}$ August 1993

Parton, N. (1997) (Ed.) Child Protection and Family Support: Tensions, Contradictions and Possibilities. London Routledge

Parton, N. (2006) Safeguarding Childhood: Early intervention and surveillance in a late modern society. London: Palgrave Macmillan

Pilgrim, D. (2017) Child sexual abuse, moral panics and emancipatory practice. Critical and Radical Social Work. Vol 5:1: 7-22

Recovery in the Bin (2016) 20 Key Principles http://www.asylumonline.net/recoveryin-the-bin/

Ryan. W. (1970) Blaming the Victim. New York: Pantheon Books.

Salter, M. (2013) Organised Sexual Abuse. Oxon: Routledge

Spandler, H. (2006) Asylum to Action: Paddington Day Hospital, Therapeutic Communities and Beyond. Jessica Kingsley Publishers, London, Philadelphia

Spandler, H. (2014) Letting Madness Breathe?: Critical challenges facing mental health social work today' in J. Weinstein. Mental Health: Critical and radical debates in social work. Policy Press, Bristol (p29-38)

Tate, T. (1998) Cleveland: Unspeakable Truths. Channel four. https://spotlightonabuse.wordpress.com/2013/05/30/cleveland-unspeakable-truths/ (Accessed 20th June 2017)

Watson, T \& Davies, L. (2013) A response to John Henley's article "Paedophilia: bringing dark desires to light." https://lizdavies.net/academia/publications/comment2/ (Accessed 27 ${ }^{\text {th }}$ June 2017) 
Weinstein, J. (2011) Case Con and radical social work in the 1970s: the impatient revolutionaries in M. Lavalette. Radical social work today: Social work at the crossroads (pp. 11-26)

White, I. and Hart, K. (1995) Report of the Inquiry into the Management of Child Care in the London Borough of Islington. The London Borough of Islington

Youle, E. (2017a) 'Islington kids' homes scandal: Why did police pull plug on new child abuse probe?' Islington Gazette. $18^{\text {th }}$ May

Youle, E. (2017b) 'Islington kids' home survivors speak out about horrific abuse still ruining their lives today'. Islington Gazette. $26^{\text {th }}$ May

Youle, E and Alwakeel, R. (2017) Islington kids' homes scandal: Shame of ex-mayor Sandy Marks' pro-paedophile past. Islington Gazette. $11^{\text {th }}$ May

\section{Biographies}

Nora Duckett is a registered social worker and Senior Lecturer at the University of Suffolk. Between 1994 and 1998 she worked as a Children and Families Social Worker for the London Borough of Harrow where Liz Davies was a Child Protection Manager. She also worked with Liz at London Metropolitan University and they have taught and written together. In 2008 their book Proactive Child Protection and Social Work was published with a second edition in 2016.

Helen Spandler is a Reader in mental health in the School of Social Work, Care and Community at the University of Central Lancashire. She interviewed Liz Davies in 1999 as part of her PhD research into Paddington Day Hospital and the Mental Patients Union, which was later published as Asylum to Action (JKP, 2006). She has written extensively about mental health and is the Managing Editor of Asylum: the magazine for Democratic Psychiatry 